\title{
Surface Colonization by and Life Cycle of Pelobacter acidigallici Studied in a Continuous-flow Microchamber
}

\author{
By ULRICH SZEWZYK AND BERNHARD SCHINK*† \\ Fakultät für Biologie, Universität Konstanz, Postfach 5560, D-7750 Konstanz, \\ Federal Republic of Germany
}

(Received 3 August 1987)

\begin{abstract}
Cells of Pelobacter acidigallici strain WoGal grown in a continuous-flow microchamber with $0 \cdot 1$ mM-gallic acid as sole carbon source attached to the surface either irreversibly (nonmotile cells) or reversibly (motile cells). At low gallic acid concentrations $(<0.1 \mathrm{mM})$ growth gave rise to microcolonies of $<128$ cells which maintained their size by release of motile swarmer cells. Continuous biofilms were formed only at higher substrate concentrations ( $>5 \mathrm{~mm}$ ), at which both growth and cell deposition at the surface took place. Under starvation conditions, motile cells ceased to grow and were washed out, whereas irreversibly attached cells continued to divide but their daughter cells did not grow. The results suggest that this bacterium when growing at an attachment surface undergoes a complex life cycle including attachment and detachment processes and formation of motile swarmer cells.
\end{abstract}

\section{INTRODUCTION}

Research on bacterial colonization of various surfaces has primarily focused on the mechanisms of attachment and on the dynamics of formation and maintenance of biofilms. Less attention has been paid to the growth of individual cells in microcolonies and biofilms. The development of microcolonies up to 16-32 cells has been studied in a continuous-flow apparatus in order to establish the kinetics of bacterial growth on surfaces (Caldwell et al., 1983; Malone \& Caldwell, 1983; Caldwell \& Lawrence, 1986). Another equation for growth of bacterial microcolonies (Davidson \& Fry, 1987) takes into consideration detachment processes in addition to attachment and growth on surfaces, and explains the occurrence of distinct bacterial colonies, and not of biofilms as predicted from the equation of Caldwell and coworkers, in aquatic environments. The formation of bigger colonies and of biofilms from distinct microcolonies of marine bacteria was studied by Pedersen (1982) using a continuous-flow chamber for long-term experiments. Glass slides which had been exposed in the flow system were removed after various times and examined microscopically. This method allowed the observation of the development of bacterial colonies and biofilms, and revealed various factors influencing surface colonization, but the discontinuity of the method did not allow direct observation of the same colony in situ with time.

All these studies were done with aerobic bacteria. Few data are available on the behaviour of anaerobic sediment bacteria on surfaces, although their natural environment is characterized by high amounts of particulate matter. To our knowledge, there is only one report on direct observation of colony formation by anaerobic bacteria, on an agar film in a system similar to the hanging-drop culture (Fortner, 1929/1930). Although anaerobic processes are commonly used in waste-water treatment, there is a lack of methods for the study of anaerobic bacteria under defined conditions. For this reason, a continuous-flow microchamber was constructed which

† Present address: Lehrstuhl Mikrobiologie I, Universität Tübingen, Auf der Morgenstelle 28, D-7400 Tübingen, FRG.

Abbreviation: SEM, scanning electron microscopy. 
allowed the cultivation of stricly anaerobic bacteria on transparent surfaces under continuous flow conditions. Surface colonization and the life cycle of the gallic-acid-fermenting bacterium Pelobacter acidigallici strain WoGal observed using this equipment are described in this paper.

\section{METHODS}

Organism. Pelobacter acidigallici strain WoGal was enriched, isolated and cultivated with gallic acid as sole energy and carbon source by a method selecting for surface-colonizing anaerobes (Szewzyk \& Pfennig, 1986).

Medium. The $\mathrm{CO}_{2}$-buffered, sodium-sulphide-reduced freshwater mineral medium used in this study has been described (Widdel \& Pfennig, 1981; Schink \& Pfennig, 1982). Trace element solution SL9 or SL10 (Tschech \& Pfennig, 1984; Widdel et al., 1983), selenite/tungstate solution (Tschech \& Pfennig, 1984), 6 vitamin solution and vitamin B12 solution (Pfennig, 1978) were added to the medium after autoclaving. Gallic acid was added from a filter-sterilized, $\mathrm{NaOH}$-neutralized $250 \mathrm{~mm}$ stock solution.

Continuous flow microchamber. The microchamber comprised a central elliptical well of $2 \mathrm{ml}$ volume which was milled into a plexiglass slide $(80 \times 30 \times 5 \mathrm{~mm})$. Two holes $(1 \mathrm{~mm}$ diameter $)$ drilled through the side of the plexiglass slide to the central chamber served as medium inlet and outlet. The central chamber was covered with two glass cover slips $(0.15 \mathrm{~mm}$ thick) the upper one of which was coated with a thin agar film on the inner side. For this purpose, $0.2 \mathrm{~g}$ agar was suspended in $100 \mathrm{ml}$ distilled water and washed five times with distilled water. The suspension was boiled, and one drop of the solution was placed on the cover slip (precleaned with ethanol). After drying, the cover slip was cemented on the plexiglass slide with silicone rubber or paraffin. The medium flowed from a 10 litre reservoir through Iso-Versinic tubing to the chamber inlet. The reservoir bottle was kept under $\mathrm{N}_{2} / \mathrm{CO}_{2}(9: 1, \mathrm{v} / \mathrm{v})$ at a pressure of approximately 50 mbar. This pressure was sufficient to pump the medium through the chamber, and the flow rate was regulated by a setscrew on the tubing. A side port septum adjacent to the inlet pipe allowed inoculation of the chamber by a hypodermic syringe. The chamber outlet was connected to a collection vessel. All parts of the continuous-flow equipment except for the chamber were sterilized by autoclaving. Before starting an experiment, the tubes were connected to the plexiglass slide, which was filled with $70 \%(\mathrm{v} / \mathrm{v})$ ethanol. A further $50 \mathrm{ml}$ of $70 \%$ ethanol was injected through the inoculation side port of the chamber and left for at least $2 \mathrm{~h}$. The ethanol was washed out by pumping 0.5 litres of growth medium through the chamber. The chamber was inoculated with $2 \mathrm{ml}$ of a late-exponential-phase culture of $P$. acidigallici strain WoGal. Continuous flow was maintained until most of the cells of the inoculum were washed out and approximately 20-50 cells per microscopic field ( $40 \times$ objective) were present in the boundary layer near the surface. Usually only the upper cover slip with the attached agar film was observed because the bacteria had to attach to this surface actively, and could not simply sediment. If nonmotile bacteria were to be observed, the flow chamber was inverted after inoculation for $30 \mathrm{~min}$, during which time continuous flow was stopped to allow the cells to settle on the agar surface. The slide was then returned to its original position and the medium flow re-started. Initially a low flow rate $\left(5 \mathrm{ml} \mathrm{h}^{-1}\right)$ was used to protect newly attached bacteria from shearing forces. After $2-4 \mathrm{~h}$, the flow rate was increased to $32 \mathrm{ml} \mathrm{h}^{-1}$, corresponding to a laminar flow speed of about $3 \mathrm{~cm} \mathrm{~min}^{-1}$ at the greatest width of the chamber.

Observation and photomicrography. The flow chamber was mounted on a Zeiss Standard microscope equipped with $16 \times$ or $40 \times$ phase-contrast optics and an Olympus OM2N camera. Kodak Technical Pan 2415, 64 ASA, film was used.

Preparation for scanning electron microscopy (SEM). The cover slip with the agar film was cemented to the microchamber with paraffin instead of silicone rubber to allow easy detachment. In early experiments, the cover slip was transferred into fixative and then increasing acetone concentrations for dehydration, but shearing forces removed many cells from the surface. To avoid such damage the fixation and dehydration procedures were carried out within the flow chamber, permitting direct observation of the cells during sample preparation. The attached cells were washed with $50 \mathrm{ml} 66.7 \mathrm{~mm}$-phosphate buffer $\mathrm{pH} 7 \cdot 2$, and then $100 \mathrm{ml}$ cooled $\left(4{ }^{\circ} \mathrm{C}\right)$ fixative $(2 \%$, v/v, glutaraldehyde in $66.7 \mathrm{mM}$-phosphate buffer $\mathrm{pH} 7.2$ ) was pumped slowly through the chamber (residence time at least $2 \mathrm{~h}$ ). The fixative was washed out of the chamber with $50 \mathrm{ml} 66.7 \mathrm{mM}$-phosphate buffer. The fixed samples were dehydrated by pumping through $50 \mathrm{ml}$ volumes of $5,10,20 \ldots 80,90,95$ and $100 \%(\mathrm{v} / \mathrm{v})$ acetone in distilled water. The cover slip was then carefully removed by melting the paraffin, washed four times in absolute ethanol and then critical-point dried prior to mounting on aluminium stubs and sputter-coating with carbon, gold and carbon. The samples were examined in a Philips model 505 SEM operated at $10 \mathrm{kV}$.

\section{RESULTS}

\section{Characterization of $P$. acidigallici strain WoGal}

$P$. acidigallici strain WoGal was isolated after enrichment from a freshwater sediment. Purity was checked several times and assured by repeated application of the agar shake technique. The 

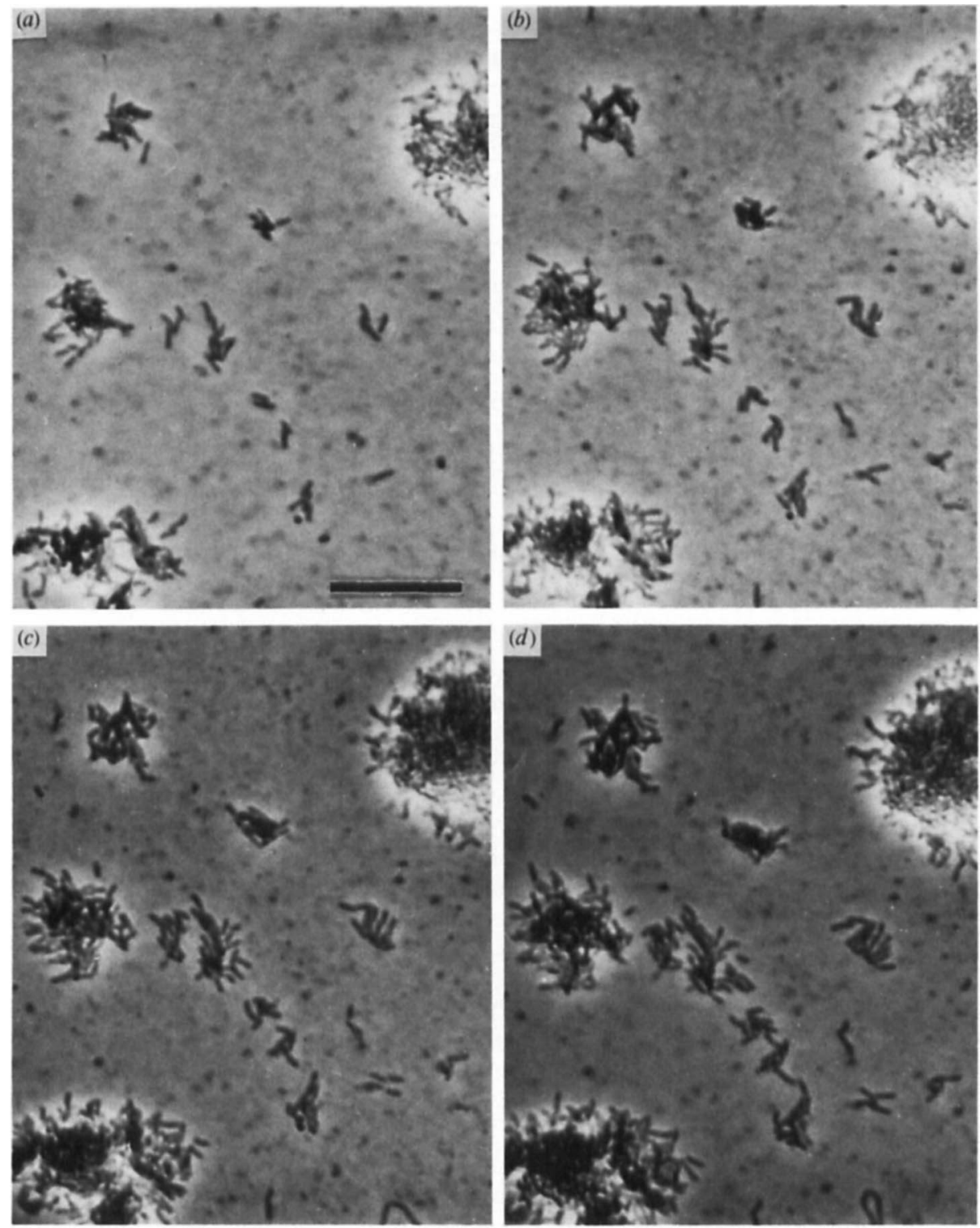

Fig. 1. Development of microcolonies during growth of $P$. acidigallici strain WoGal with $0 \cdot 1 \mathrm{~mm}$-gallic acid as substrate at an agar-coated glass surface in the flow chamber. Pictures were taken after $(a) 0 \mathrm{~h}$, (b) $3.6 \mathrm{~h},(c) 5 \mathrm{~h}$, and $(d) 6 \mathrm{~h}$, as described in Methods. Bar, $5 \mu \mathrm{m}$.

cells were straight to slightly curved Gram-negative rods $(0 \cdot 4-0 \cdot 6 \times 3-5 \mu \mathrm{m})$. They were usually nonmotile, but motility of a small proportion of the cells was observed in newly isolated batch cultures. Out of 30 substrates tested (including sugars, formate, pyruvate and different aromatic compounds), only pyrogallol and gallic acid were fermented.

\section{Primary colonization events}

After inoculation of the flow chamber, nonmotile cells always attached irreversibly, with the whole length of the cell in contact with the agar surface, and twitching motility was never observed. In contrast, motile cells normally attached to the substratum at only one pole of the 
cell; the other part of the cell extended into the boundary layer and exhibited active twitching motility for up to 3 to $4 \mathrm{~d}$. This phase could be interrupted either by detachment and subsequent active movement, or by irreversible attachment and loss of twitching motility. Both cell types (irreversibly attached or twitching) could undergo binary fission. Daughter cells of irreversibly attached cells were also non-motile, and they remained close to the mother cell, forming a microcolony. Daughter cells of reversibly attached, twitching cells either attached loosely to the surface or swam away into the liquid phase. Reversibly attached cells never formed microcolonies until they had attached irreversibly.

\section{Estimation of doubling time}

Observation of colony formation allowed an estimation of the doubling times of the irreversibly attached bacteria at various substrate concentrations, since individual cells could be distinguished and counted by photomicroscopy up to the eight-cell stage of colony formation. The doubling time at the surface at high substrate concentrations $(2.5 \pm 0.5 \mathrm{~h}$ with gallic acid concentrations $\geqslant 1 \mathrm{mM}$ ) was comparable to that in liquid batch culture at the same substrate concentrations. The doubling time of the cells at the surface increased to $3.4 \pm 0.2 \mathrm{~h}$ with $0.1 \mathrm{~mm}$-gallic acid and to more than $10 \mathrm{~h}$ with gallic acid concentrations $\leqslant 0.01 \mathrm{mM}$, although under the latter conditions exact measurement was not possible due to detachment of motile swarmer cells.

\section{Formation and maintenance of microcolonies}

The development and behaviour of single microcolonies of $P$. acidigallici strain WoGal could be observed over a long period at low nutrient conditions since cell sedimentation from the liquid phase was negligible. Colony development on the agar surface is shown in Fig. 1. The microcolonies only reached a certain size, depending on the substrate concentration in the inflowing medium. Maintenance of colony size was observed with $\leqslant 0 \cdot 1 \mathrm{mM}$-gallic acid in the inflowing medium. After the colony had reached a certain size $(\approx 100-200$ cells for $0.1 \mathrm{~mm}$ substrate), peripheral cells were observed which extended radially from the colony and showed twitching motility. After 1-3 h the motile cells detached and migrated into the liquid phase. These motile swarmer cells expressed the same behaviour at a surface as motile cells did after inoculation.

\section{Development of biofilms}

When the gallic acid concentration in the inflowing medium was $>0.1 \mathrm{~mm}$, biofilm development was observed within $10-15 \mathrm{~d}$ of inoculation. The structure of the developing biofilm varied depending on the substrate concentration. At high gallic acid concentrations ( $\geq 5 \mathrm{mM}$ ), high numbers of suspended cells led to a high deposition rate, resulting in a homogeneous biofilm within 3-6 d of inoculation. At lower gallic acid concentrations $(0 \cdot 1-$ $1 \mathrm{~mm}$ ) the number of suspended cells was much lower. Due to a low deposition rate the microcolonies remained solitary for longer, and development could be observed upto the 128-cell stage or beyond. After $8 \mathrm{~d}$, the area between the well-developed colonies was covered with smaller microcolonies and single cells which were deposited from the boundary layer (Fig. 2). Even after $25 \mathrm{~d}$ incubation, the heterogeneous structure of the biofilm was still apparent.

\section{Starvation experiments}

A biofilm and surrounding colonies, which has developed in the continuous flow microchamber with $1 \mathrm{mM}$-gallic acid in the inflowing medium, was starved for $8 \mathrm{~d}$ by omitting gallic acid from the medium. The first change, observed after 1-2 d, was that the short, curved, highly motile cells became 3-10-fold longer, and movement slowed down considerably. These elongated cells did not multiply and were washed out within 1-2 d. Reattachment of these cells was never observed. The resting nonmotile cells also underwent morphological changes. Initially, they showed loss of contrast when examined by phase-contrast microscopy, and $24 \mathrm{~h}$ later they had decreased in size. This was due to cell division without growth of the daughter cells. Further changes such as detachment or formation of motile cells were not observed. 


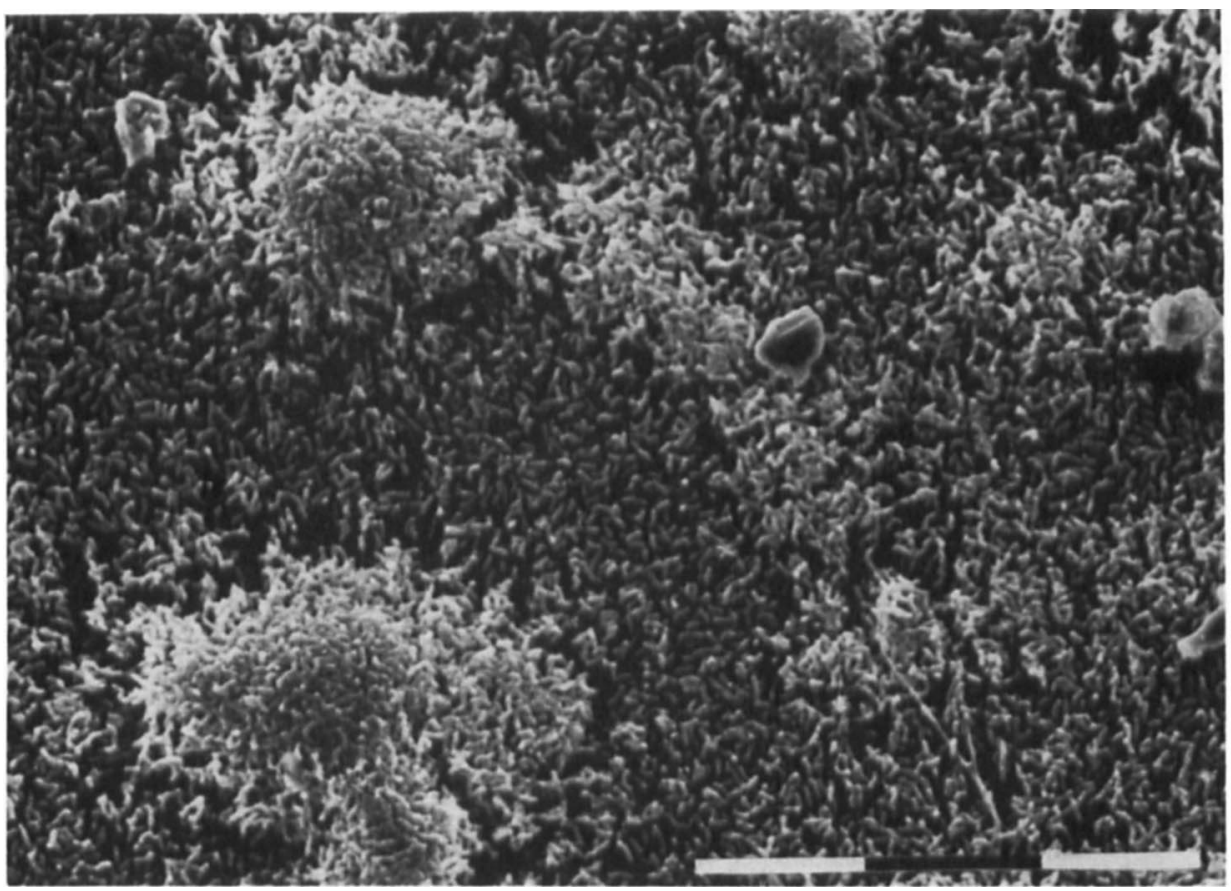

Fig. 2. SEM photograph of the same microcolonies as shown in Fig. 1, after the end of the experiment (8 $\mathrm{d}$ incubation). Bar, $10 \mu \mathrm{m}$.

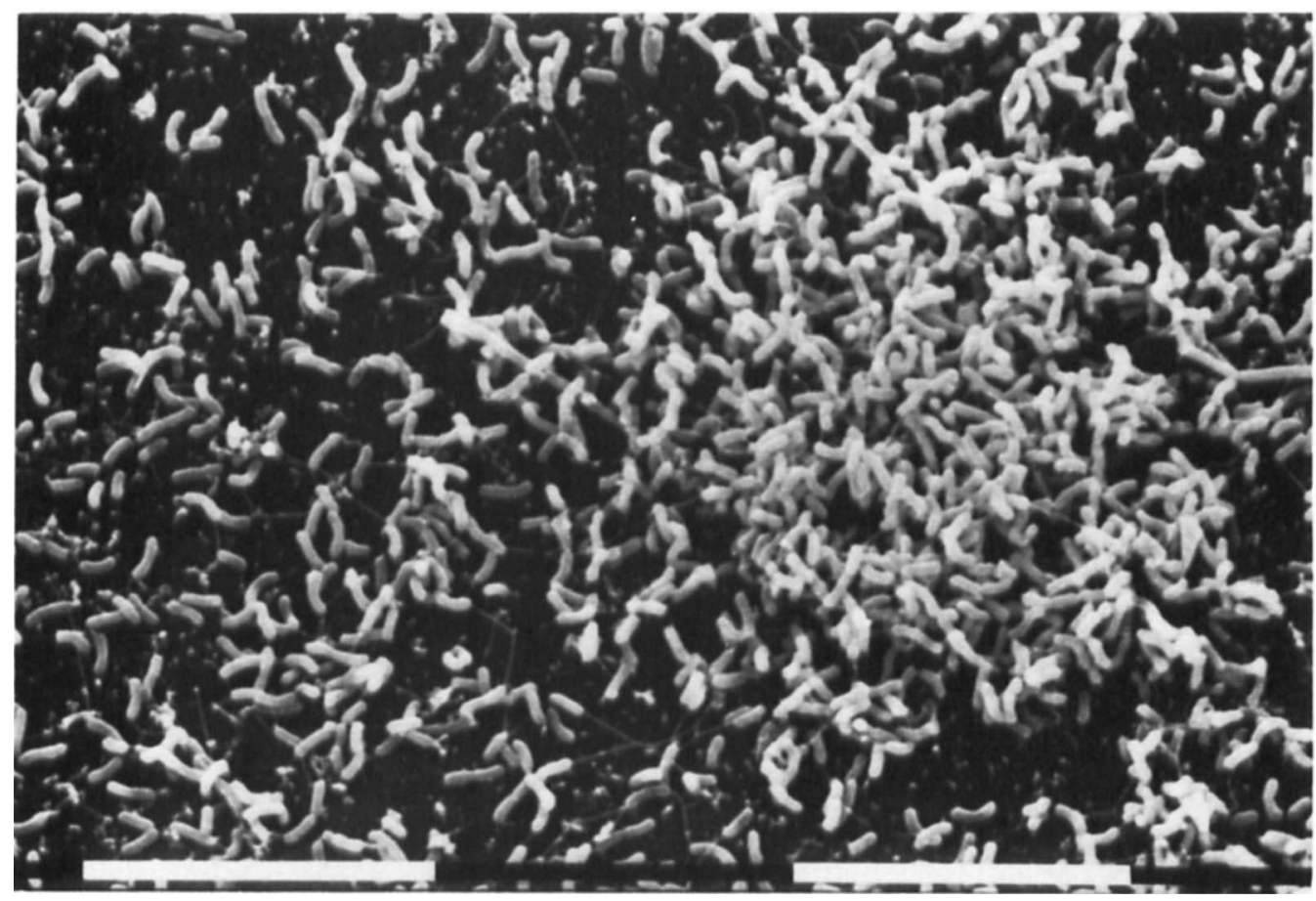

Fig. 3. SEM photograph of a microcolony of $P$. acidigallici strain WoGal showing the spongy structure of the colony and the threads connecting the cells. Bar, $10 \mu \mathrm{m}$. 
After $8 \mathrm{~d}$ starvation, gallic acid was added back to the medium reservoir (final concentration $0.01 \mathrm{mM}$ ). Three days later, the first motile cells appeared; these were longer than those observed at the beginning of the experiment. Only a proportion of the cells in the biofilm and the colonies were able to grow. Most growth occurred in new microcolonies which developed from single deposited motile cells. SEM examinations of the microcolonies (Fig. 3) showed a spongy structure. The distance between individual bacteria in a microcolony was large and the space between the cells was filled with threads which probably represent remnants of condensed, dehydrated exopolymers.

\section{DISCUSSION}

The present studies on the behaviour of an anaerobic bacterium at an agar/liquid interface were carried out in a specially developed continuous-flow apparatus. In contrast to continuousflow chambers and slide cultures described earlier (Quesnel, 1969; Marshall, 1986; Caldwell \& Lawrence, 1986), our flow chamber allowed direct observation of anaerobic bacteria over long time periods. In addition, all preparation steps for SEM examinations could be carried out carefully in situ in the chamber. During fixation and continuous dehydration, no loss of bacteria from the surface was observed, in contrast to other studies (Richards \& Turner, 1984).

The results of experiments with $P$. acidigallici strain WoGal presented here indicate that the growth rates at the surface, over a wide range of substrate concentrations $(\leq 0 \cdot 1 \mathrm{mM}-10 \mathrm{mM})$, are very similar to the growth rates calculated for suspended cells. With $<0.1 \mathrm{~mm}$-gallic acid in the inflowing medium, the growth rate at the surface decreased. In principle, our results on the dependence of growth rate on substrate concentration are in good agreement with the findings for a strain of Pseudomonas fluorescens (Caldwell \& Lawrence, 1986).

Our observations on the behaviour of cells of $P$. acidigallici strain WoGal at an agar/liquid interface can be summarized in a life cycle (Fig. 4). The major parts of this life cycle are the attachment of suspended cells, growth of these cells and subsequent formation of microcolonies and the formation of motile swarmer cells.

The results regarding the primary attachment behaviour of $P$. acidigallici strain WoGal are similar to the observations recorded for several aerobic bacteria (Kefford \& Marshall, 1984; Marshall et al., 1971). In contrast to the observations with the pseudomonad (Marshall et al., 1971), both motile and nonmotile cells of $P$. acidigallici strain WoGal attached to the surface. Whilst the nonmotile cells always attached irreversibly, the motile cells often attached only for a short time, detached, and re-attached somewhere near the old attachment place. The frequent repetition of this process also under substrate-limiting conditions suggests that the energy needed to overcome attraction forces at the surface is not high.

The irreversibly attached cells divided and formed microcolonies. The size of the solitary colonies was maintained by formation and release of motile swarmer cells in the outer part of the colonies. The detachment process observed during liberation of swarmer cells from a colony is interesting in view of the detachment mechanism. SEM photographs of critical-point-dried microcolonies of strain WoGal showed many connecting threads between the bacteria (Fig. 3). Similar threads in critical-point-dried biofilms were interpreted by Richards \& Turner (1984) as remnants of the glycocalyx of the bacteria after dehydration and critical-point drying. In airdried surface colonies of $P$. acidigallici strain WoGal from other experiments, the cells appeared to be embedded in a slimy matrix. When swarmer cells in the outer part of a microcolony detach, they have to break their glycocalyx connection to the other bacteria. In this case, an active release of the glycocalyx by the swarmer cell, as decribed for Pseudomonas sp. (Wrangstadh et al., 1986) under starvation conditions, seems probable. The release of motile swarmer cells by colonies of $P$. acidigallici strain WoGal appears to be comparable to swarmer cell formation by different aerobic, sheath-forming bacteria, e.g. Sphaerotilus natans (Dow \& Whittenbury, 1980).

The formation of homogeneous, thick biofilms that was observed at high substrate concentrations ( $\geq 5 \mathrm{~mm}$-gallic acid) appears to be a special case and of minor importance for most natural environments, which are characterized by low substrate concentrations. At lower substrate concentrations $(0 \cdot 1-5 \mathrm{mM})$ the biofilm developed from originally distinct microcolon- 


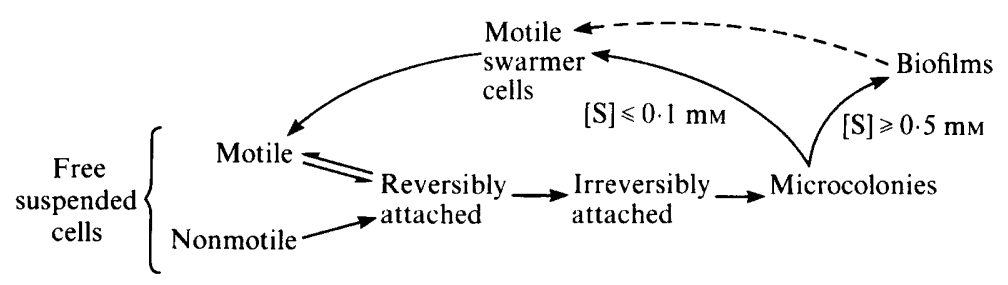

Fig. 4. Scheme of the proposed life cycle of $P$. acidigallici strain WoGal. The life cycle includes attachment and detachment of cells as well as swarmer cell formation.

ies which subsequently merged, and the resulting biofilm was heterogeneous. These findings are important for the discussion of biofilm formation kinetics. All models of microbial biofilm formation developed so far are based on a homogeneous structure of the film (Rittmann \& McCarty, 1980; Bryers \& Characklis, 1982; Kreikenbohm \& Stephan, 1985). However, in natural environments, e.g. in lakes or ponds, and in several types of industrial plant (e.g. heat exchangers), substrate concentrations are low. Thus existing models of biofilm formation and maintenance may be only relevant to special systems where high substrate concentrations or high numbers of suspended cells are present.

The authors are greatly indebted to Professor Dr N. Pfennig for support and valuable criticism. This work was supported by the Deutsche Forschungsgemeinschaft.

\section{REFERENCES}

Bryers, J. D. \& Characklis, W. G. (1982). Process governing primary biofilm formation. Biotechnology and Bioengineering 24, 2451-2476.

Caldwell, D. E. \& Lawrence, J. R. (1986). Growth kinetics of Pseudomonas fluorescens microcolonies within the hydrodynamic boundary layers of surface microenvironment. Microbial Ecology 12, 299-312.

Caldwell, D. E., Malone, J. A. \& Kieft, T. L. (1983). Derivation of a growth rate equation describing microbial surface colonization. Microbial Eco$\log y$ 9, 1-6.

Davidson, A. M. \& FrY, J. C. (1987). A mathematical model for the growth of bacterial microcolonies on marine sediment. Microbial Ecology 13, 31-45.

Dow, C. S. \& Whittenbury, R. (1980). Prokaryotic form and function. In Contemporary Microbial Ecology, pp. 391-417. Edited by D. C. Ellwood, J. N. Hedger, M. J. Latham, J. M. Lynch \& J. H. Slater. London: Academic Press.

FORTNER, J. (1929/30). Die Mikroskopie der aeroben und anaeroben Oberflächenkolonien auf hängendem Agar. Zentralblatt für Bakteriologie, Parasitenkunde und Infektionskrankheiten, 1. Abteilung, Originale 115, 96-99.

KefFoRd, B. \& MARShall, K. C. (1984). Adhesion of Leptospira at a solid-liquid interface - a model. Archives of Microbiology 138, 84-88.

KreIKENBOHM, R. \& STEPHAN, W. (1985). Application of a two-compartment model to the wall growth of Pelobacter acidigallici under continuous culture conditions. Biotechnology and Bioengineering 27, 296301.

Malone, J. A. \& Caldwell, D. E. (1983). Evaluation of two surface colonization equations in continuous culture. Microbial Ecology 9, 299-305.
Marshall, K. C. (1986). Microscopic methods for the study of bacterial behavior at inert surfaces. Journal of Microbiological Methods 4, 217-227.

Marshall, K. C., Stout, R. \& Mitchell, R. (1971). The mechanism of the initial events in the sorption of marine bacteria to surfaces. Journal of General Microbiology 68, 337-348.

Pedersen, K. (1982). Method for studying microbial biofilms in flowing-water systems. Applied and Environmental Microbiology 43, 6-13.

Pfennig, N. (1978). Rhodocyclus purpureus gen. nov. and sp. nov., a ring-shaped vitamin $\mathbf{B}_{12}$-requiring member of the family Rhodospirillaceae. International Journal of Systematic Bacteriology 28, 283-288.

QUESNEL, L. B. (1969). Methods of microculture. Methods in Microbiology 1, 365-425.

RICHARDS, S. R. \& TURNER, R. J. (1984). A comparative study of techniques for the examination of biofilms by scanning electron microscopy. Water Research 18, 767-773.

RittmanN, B. E. \& McCarty, P. L. (1980). Model of steady-state-biofilm kinetics. Biotechnology and Bioengineering 22, 2343-2357.

SCHINK, B. \& PFENNIG, N. (1982). Fermentation of trihydroxybenzenes by Pelobacter acidigallici gen. nov. sp. nov., a new stricly anaerobic, non-sporeforming bacterium. Archives of Microbiology 133, 195-201.

SzewzyK, U. \& PfenNig, N. (1986). A simple method for enrichment and cultivation of anaerobic, surfacecolonizing bacteria. Journal of Microbiological Methods 5, 289-294.

TSCHECH, A. \& PFENNIG, N. (1984). Growth yield increase linked to caffeate reduction in Acetobacterium woodii. Archives of Microbiology 137, 163-167. 
Widdel, F. \& PfEnNIG, N. (1981). Studies on dissimilatory sulfate reducing bacteria that decompose fatty acids, I. Isolation of new sulfate-reducing bacteria enriched with acetate from saline environment. Description of Desulfobacter postgatei gen. nov. sp. nov. Archives of Microbiology 129, 395-400.

WIDdel, F., Kohring, G. W. \& MAYeR, F. (1983). Studies on dissimilatory sulfate-reducing bacteria that decompose fatty acids. III. Characterization of the filamentous gliding Desulfonema limicola gen. nov. sp. nov., and Desulfonema magnum sp. nov. Archives of Microbiology 134, 286-294.

Wrangstadh, M., Conway, P. L. \& Kjelleberg, S. (1986). The production of an extracellular polysaccharide during starvation of a marine Pseudomonas sp. and the effect thereof on adhesion. Archives of Microbiology 145, 220-227. 